\title{
Corn Growth and Yield on Suboptimal Upland Soil After Amended with Biochar and Low Levels of Fertilizer in West Kalimantan, Indonesia
}

\section{Pertumbuhan dan Hasil Jagung pada Tanah Dataran Tinggi Suboptimal Setelah Diubah dengan Biochar dan Pupuk Kadar Rendah di Kalimantan Barat, Indonesia}

\author{
Sutarman Gafur $^{1^{\star}}$, Saeri Sagiman ${ }^{1}$, Tatang Abdurrahman ${ }^{2}$ \\ ${ }^{1}$ Department of Soil Science, Faculty of Agriculture, Universitas Tanjungpura \\ 2. Department of Agrotechnology, Faculty of Agriculture, Universitas Tanjungpura \\ "Email:sutarman.g@faperta.untan.ac.id
}

Disubmit: 15 September 2019

Direvisi: 27 Desember 2019

Diterima: 24 Januari 2020

\begin{abstract}
Abstrak: Biochar sudah terkenal sebagai bahan amandemen tanah yang memiliki potensi besar untuk meningkatkan sifat tanah yang terdegradasi. Namun, untuk memaksimalkan perannya dalam meningkatkan karakteristik tanah yang penting untuk mendukung pertumbuhan tanaman, perlu dikombinasikan dengan bahan potensial lainnya. Dalam penelitian ini kami mencari paket perlakuan yang berpotensi bermanfaat dan terjangkau secara lokal. Eksperimen ini dirancang untuk mempelajari efek biochar dan input rendah dari paket perlakuan NPK pada pertumbuhan jagung dan hasil di tanah dataran tinggi suboptimal Kalimantan Barat, dan untuk mempelajari dampak dari perawatan ini pada beberapa karakteristik tanah yang penting. Empat tingkat perlakuan yang digunakan: T0 (kontrol), T1 (Biochar 5\% (W / W), dan NPK 300kg / ha), T2 (Biochar 5\%, dan NPK $600 \mathrm{~kg} / \mathrm{ha}$ ), T3 (Biochar 10\% dan NPK300 kg / ha, dan T4 (Biochar 10\% dan NPK $600 \mathrm{~kg} / \mathrm{ha}$ ). Setiap perlakuan memiliki empat ulangan. Hasilnya menunjukkan bahwa total berat kering tanaman meningkat dari $151 \mathrm{~g} /$ tanaman (T1) menjadi $237 \mathrm{~g} /$ tanaman (T4), sedangkan total produksi jagung meningkat dari 12,9 (T1) menjadi 15,7 ton / ha (T4). Selanjutnya, semua paket perlakuan juga secara signifikan meningkatkan $\mathrm{pH}$ tanah, kandungan C-organik, KTK, dan rasio $\mathrm{C} / \mathrm{N}$ tanah. Selain itu, kandungan N, P, K, di tanah pada akhir percobaan juga meningkat rata-rata 163, 1143, dan 432\%, masing-masing. Singkatnya, semua perawatan berbasis biochar secara signifikan meningkatkan pertumbuhan tanaman, hasil panen, dan beberapa karakteritik tanah yang penting. Kami sangat merekomendasikan T3, dengan kadar NPK lebih rendah dari biasanya, sebagai paket perawatan yang akan diuji lebih lanjut di lahan dataran tinggi suboptimal di Kalimantan Barat..
\end{abstract}

Kata kunci: Jagung (Zea mays L.), Lahan kering, Pertukaran kalium, Pupuk organik dan Anorganik

\begin{abstract}
Biochar is already well-known as a soil amendment material that has great potential to improve degraded soil properties. However, in order to maximize its role in improving important soil characteristics to support plant growth, it needs to be combined with other potential materials. In this study we are seeking a treatment package that is potentially useful and locally affordable. This experiment is designed to study the effects of biochar and low input of NPK treatment packages on corn growth and yield in suboptimal upland soil of West Kalimantan, and to study the impact of these treatments on some important soil characteristics. Four treatment levels were used: T0 (control), T1 (Biochar 5\% (W/W), and NPK 300kg/ha), T2 (Biochar 5\%, and NPK $600 \mathrm{~kg} / \mathrm{ha})$, T3 (Biochar 10\% and NPK300 kg/ha, and T4 (Biochar 10\% and NPK $600 \mathrm{~kg} / \mathrm{ha}$ ). Each treatment had four replications. The results show that total plant dry weight increased from $151 \mathrm{~g} / \mathrm{plant}$ (T1) to $237 \mathrm{~g} / \mathrm{plant}$ (T4), while total corn production increased from 12.9 (T1) to 15.7 ton/ha (T4). Furthermore, all treatment packages also significantly increased soil $\mathrm{pH}$, C-organic content, $\mathrm{CEC}$, and soil $\mathrm{C} / \mathrm{N}$ ratios. Moreover, the content of $N, P, K$, in the soil by the end of the experiment also increased on average 163, 1143, and $432 \%$, respectively. In short, all biochar based treatments significantly increased plant growth, yields, and some important soil charactersitics. We highly recommend T3, with lower NPK levels than normally recommended, as a treatment package to be further field tested in suboptimal upland soil in West Kalimantan.
\end{abstract}

Keywords: Biochar, Low inputs, Upland soil,Corn growth and Yield 


\section{PENDAHULUAN}

The area of upland soil in West Kalimantan that is potentially used for upland rice and horticulture crops is about 233.946 hectars (BPS Kal Bar, 1992). Specifically, the land that is able to be used for upland rice is only about 138.723 ha. However, the total harvest of upland rice in 2013 as reported to be only 103.972 hectars (BPS Kal Bar, 2014). The potency of upland soil will be a very important and meaningfull resource for increasing the productivity and food self-sufficiency in this province.

The upland soil of West Kalimantan is already known as moderately old to severely degraded land. Moderately degraded upland soil is generally widespread in agricultural land areas, while severely degraded land is mostly found in illegal mine site areas. The impact of this low quality degraded land is its low productivity level. It is reported that the average upland rice productivity in West Kalimantan is only about $1900 \mathrm{~kg}$ per hectar (BPS Kal Bar, 2014). Therefore, in order to use upland soil in West Kalimantan for food crop development, there is a need to find specific local technology that is able not only to upgrade upland soil characteristics but also to improve plant growth and its yields.

Biochar research is already well-known worldwide, and it is also known for having great potentialities to improve some important soil characteristics (Zong et al. 2015; Yoo et al. 2013). Black biochar is known for having wide internal surface areas and high in micro pores so that it would be a high quality absorbent material (Downie et al. 2009). This absorbent function is highly expected in retaining soil nutrients and preventing their loss from the soil through the erosion process. It is also known that Some important impacts of biochar application were improving soil CEC, reusing plant residue, reducing surface run-off, decreasing water and fertilizers use, increasing crop yield, improve soil biodiversity, strengthening and building soil foodweb, improving soil carbon storage, increasing soil $\mathrm{pH}$, restructuring degraded land, and reducing methane and ammonia gases emisson from agricultural land (Ekebafe et al. 2015). However, biochar is not yet widely used as part of agricultural technology in West Kalimantan. Good impact of biochars could be a prospect to upgrade the characteristics of upland soil in West Kalimantan and to support the development of sustainable agriculture in this areas. However, biochar is not the only resource that could upgrade soil quality. Another suggestion is to combine biochar with other materials in order to maximize its role in improving soil characteristics (Wimmer, 2011).

Low input agricultural systems might be regarded as unacceptable or an impossible agricultural system to overcome the handicaps faced in upland agricultural systems in West Kalimantan. In fact, for the poor farmers in this province low input agricultural systems might be the only one they can apply, especially the one which use more local resources as it is believed able to increase land quality and productivity. Combining the use of biochar, compost, and low doses of inorganic fertilizers look promising in developing a simple and adoptable crop culture technology to support sustainable agricultural system in West Kalimantan. Biochar, that is having high water retention and absorption, and also slow in nutrient release, is regarded as an approriate choice to improve the quality of suboptimal upland soil properties. On the other hand, compost of empty bunch of oil palm fruits and cow manure are able to improve not only the soil physical properties but also to the nutrient storage to enrich the soil's chemical and biological properties. Specifically low input of NPK is expected to provide early need of the plants so that the plants 
can grow as potentially expected. Eventually, collectively, effects of this combination of treatments will result in better soil quality and increasing crop productivity. Gradually, this low input system is believed to be able to improve physical, chemical, and biological soil properties. In turn, this system will slowly improve land productivity that benefit the farmers. Finally, this experiment was designed with as its main objectives to study the effects of biochar, compost, and low input of NPK treatment packages on corn growth and yields in suboptimal upland soil of West Kalimantan, and also to study the treatment impact on some important soil characteristics.

\section{MATERIALS AND METHODS}

\section{Materials Preparation and Experimental Design}

Soils used in this experiment were collected from the Village of Toho, Subdistrict of Toho, West Kalimantan, Indonesia, in April 2017. Its chemical and physical propoerties were analysed in Soil Chemical Laboratory, Faculty of Agriculture, Tanjungpura University, and prepared for growth media in polybag. Biochars were made from rice husk burnt in controlled burning called pyrolysis technique. Composts were made by mixing empty bunch of palm oil and cow manure by 50:50 percent for each composition and left for two weeks for its incubation process. Soils were mixed with biochars, and composts based on each treatment doses, while for NPK compound fertilizers were applied a day before planting. The corn seeds used were commercial hybrid corn type called as Pioneer.

The selected corn seeds were grown in the polybags arranged in a Completely Randomized Design. There were four levels treatment applied which were known as T0 as control, T1 (Biochar 5\% (W/W), Compost 2.5\% (W/W), and $300 \mathrm{~kg} / \mathrm{ha}$ NPK), T2 (Biochar 5\%, Compost 2.5\%, and $600 \mathrm{~kg} / \mathrm{ha} \mathrm{NPK}$ ), T3 (Biochar 10\%, Compost $2.5 \%$, and $300 \mathrm{~kg} / \mathrm{ha} \mathrm{NPK}$, and T4 (Biochar 10\%, Compost 2.5\%, and $600 \mathrm{~kg} / \mathrm{ha} \mathrm{NPK).}$ Each treatment has 4 replications.

In this experiment there were 2 group parameters to be observed. For plant growth parameters they were measured as plant height at 5,6 , and 7 weeks after planting, total biomas, and plant dry weight after harvesting. Plant productions were predicted from yield per plant and total plant population per hectar. Soil parameters observed were soil $\mathrm{pH}$, total- $\mathrm{N}$, total $\mathrm{P}$, available $\mathrm{P}$, exchangeable $\mathrm{Al}, \mathrm{Fe}, \mathrm{K}, \mathrm{Ca}, \mathrm{Mg}$, and $\mathrm{Na}$. They were twicely measured, before the treatment were applied and at the end of the research activities.

\section{Statistical Analysis}

Statistical analyses for mean of each variable were performed using the procedure according to Gomez and Gomez (2007). Firstly, all data were tabulated using Microsoft Excel 2007, and analyzed using One Way-ANOVA, and when there is a significant effect of the treatment, then continued with Duncan's Multiple Range Test at $5 \%$ significant level. 


\section{RESULTS AND DISCUSSION}

\section{Corn Growth and Yield}

\section{Corn Growth and Yield}

Growth response of corn at each treatment package were presented at the following Figure 1.

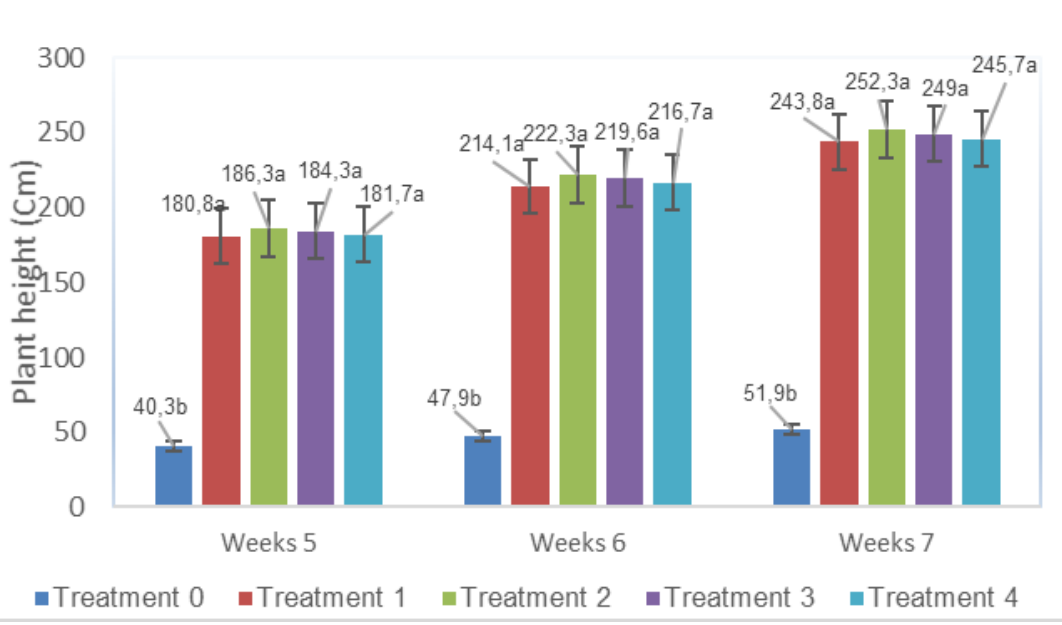

Figure 1. Corn growth responses at each treatment after 5, 6, and 7 weeks after planting.

Figure 1 shows that the corn were highly responsive to all biochar treatment packages, since plant height at all treatment package (T1 to T4) were significantly different compared to that of control treatment (T0). Eventhough, there is no significntly different in plant height response among biochar treatment package, the highest plant height was occured at treatment 2 at which $5 \%$ biochar and $600 \mathrm{~kg}$ NPK per hectar were applied.

Other growth response parameters were wet and dry weight of above ground plant parts as presented in Figure 2. They show similar trend that the highest weight was occured at treatment 4 . It is mostly to occur because at treatment 4 were applied $10 \%$ biochar and $600 \mathrm{~kg} \mathrm{NPK}$ per hectar. However, these responses were not statistically significantly different with that of in treatment 3 at which there were $10 \%$ biochar and only $300 \mathrm{~kg}$ NPK per hectar applied.

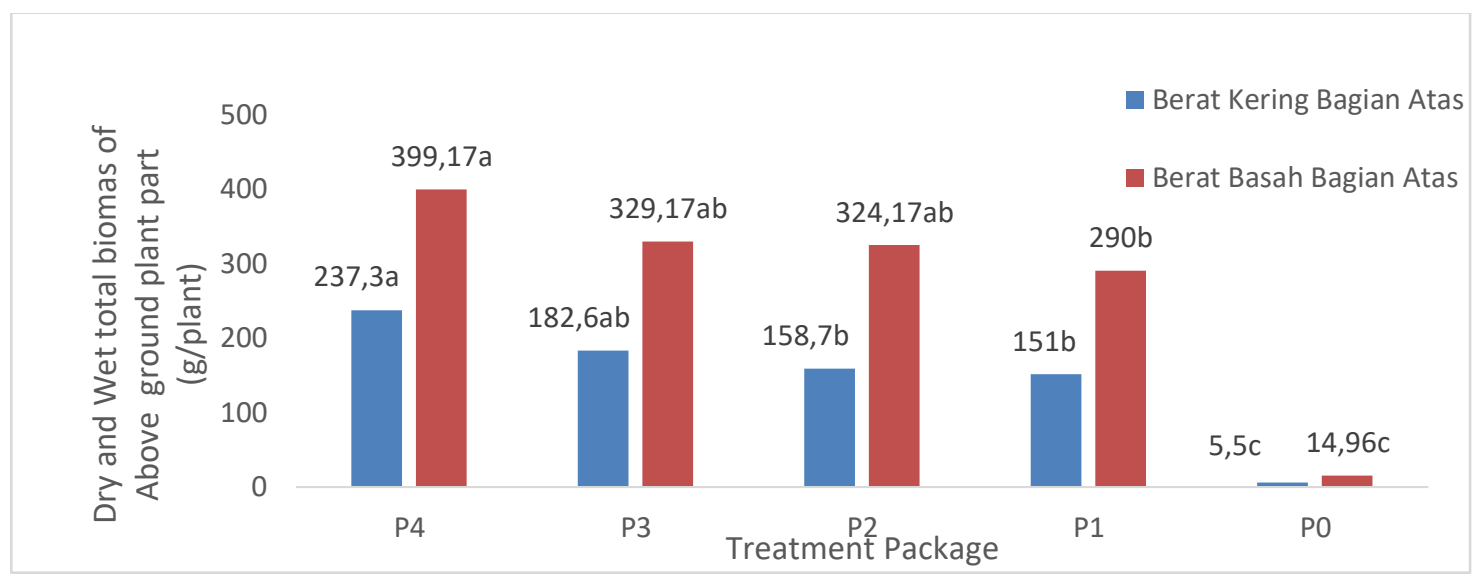

Figure 2. Total Biomas showed as Wet and Dry weight of above ground plant parts at harvest for each treatment package. 
Corn yield per plant and total production per hectar were presented in the following table (Table 1).

Table 1. Corn Yield per plant (g), and Total Production Prediction per hectar (ton), the average length of corn knob per plant $(\mathrm{cm})$, and average weight of 10 seeds $(\mathrm{g})$ for each treatment.

\begin{tabular}{ccccc}
\hline Treatment Package & $\begin{array}{c}\text { Corn } \\
\text { Yield per } \\
\text { plant (g) }\end{array}$ & $\begin{array}{c}\text { Predicted } \\
\text { Total } \\
\text { Prodution per } \\
\text { hectar (ton) }\end{array}$ & $\begin{array}{c}\text { The } \\
\text { length of } \\
\text { corn knob } \\
\text { (cm) }\end{array}$ & $\begin{array}{c}\text { The } \\
\text { average } \\
\text { weight of } \\
\text { 10 seeds } \\
\text { (g) }\end{array}$ \\
\hline $\begin{array}{c}\text { Biochar 5\%+Compost } \\
2.5 \%+N P K ~ 600 k g / h a(T 2) \\
\text { Biochar 10\%+Compost }\end{array}$ & $209,74 \mathrm{a}$ & $15,73 \mathrm{a}$ & $16,25 \mathrm{a}$ & $4,64 \mathrm{a}$ \\
$\begin{array}{c}2.5 \%+N P K ~ 300 \mathrm{~kg} / \mathrm{ha}(\mathrm{T} 3) \\
\text { Biochar 10\% + Compost }\end{array}$ & $207,58 \mathrm{a}$ & $15,58 \mathrm{a}$ & $15,79 \mathrm{a}$ & $4,27 \mathrm{a}$ \\
$\begin{array}{c}2.5 \%+\mathrm{NPK} 600 \mathrm{~kg} / \mathrm{ha}(\mathrm{T} 4) \\
\text { Biochar 5\% + Compost }\end{array}$ & $184,55 \mathrm{a}$ & $13,84 \mathrm{a}$ & $15,62 \mathrm{a}$ & $4,59 \mathrm{a}$ \\
$\begin{array}{c}2.5 \%+\mathrm{NPK} 300 \mathrm{~kg} / \mathrm{ha}(\mathrm{T} 1) \\
\text { Control (T0) }\end{array}$ & $171,39 \mathrm{a}$ & $12,85 \mathrm{a}$ & $14,67 \mathrm{a}$ & $4,02 \mathrm{a}$ \\
\hline
\end{tabular}

Note: Figures within the same colums followed by the same letters were not significantly different at $5 \%$ significant level.

Table 1 above shows that statistically there is not a significant different among all biochar base treatments for corn production level. However, it is interesting to be discussed that for treatment 2 and 3 , at which they have two higher production levels, they were having different package proportion level. For treatment 2, it has highest production level, and it is believed due to its highest NPK level (600 kg NPK/ha) as it is recommended. This response was similar to that of growth response as it is presented in Figure 1, however, it is not similar to the response on wet and dry weight. Interestingly, at treatment 3 at which biochar dose increased to $10 \%$ and NPK dose was only $300 \mathrm{~kg} / \mathrm{ha}$, its production level was statistically similar to that of treatment 2 at which its NPK level was double. For its productivity and economic reasons that both tretament 2 and 3 are recommended for further field tests. The result also shows that the seed quality was relatively similar (Table 1), at which the average weight of 10 seeds were similar among the treatments. It means that the corn seed average size within each knob is realtively similar. More importantly that the treatments of biochar, compost, and both low input and recommended doses of NPK had successfully increased both the growth and yield of corn grown in suboptimal upland soil at Subdistrict of Toho, West Kalimantan. Furthermore, all the treatment packages had successfuly prevented them from the failure of growth and production as it was occured in the control treatment (T0).

Generally, above findings show a similar trend with the findings of Carter et al., (2013) that biochar application were able to increase total biomass, root biomass, and plant growth of Lactuca sativa and Brassica chinensis. It was also reported that rice husk biochars were able to increase the growth of mustard-greens (Suryana et al. 2016).

\section{Soil $N, P$, and $K$ Content at the end of the experiment.}

The treatment package of biochar, compost, low input of NPK had greatly increased soil N, P, and K content by the end of the experiment (Table 2). Soil N and $\mathrm{K}$ content had significantly increased at all treatment package, it might be due to high 
content of $\mathrm{K}$ found in rice husk biochar and high $\mathrm{N}$ content contributed from the compost compared to that of found in control treatment soil. Specifically for soil $\mathrm{P}$, its content only significantly different from that content of in treatment 4 at which it has the highest of NPK compound applied. It could be concluded that low input of NPK applied together with rice husk biochar and compost had significantly increased the residue of $\mathrm{N}, \mathrm{P}$, and $\mathrm{K}$ within the soil. These increases were resulted from collective impact of biochar and compost applied. Biochar is known as better absorant for soil nutrients so that it will retain more soil nutrients, while compost will contribute for the availability of soil nutrients. These residue will be a prospective soil nutrient resources that might be available and ready for use in the next following planting period.

Table 2. Soil macro nurient content of $\mathrm{N}, \mathrm{P}$, and $\mathrm{K}$ by the end of the experiment.

\begin{tabular}{|c|c|c|c|}
\hline Treatment Package & $\mathbf{N}(\%)$ & $\mathrm{P}_{2} \mathrm{O}_{5}(\mathrm{ppm})$ & $\begin{array}{c}\text { K-dd } \\
\left(\mathrm{cmol}^{+}\right)\left(\mathrm{kg}^{-1}\right)\end{array}$ \\
\hline $\begin{array}{l}\text { Biochar } 10 \%+\text { Compost } 2.5 \% \\
\text { +NPK } 600 \mathrm{~kg} / \mathrm{ha}(\mathrm{T} 4)\end{array}$ & $0,37 a$ & $121,07 a$ & $0,52 a$ \\
\hline $\begin{array}{l}\text { Biochar } 10 \%+\text { Compost } 2.5 \% \\
+ \text { +NPK } 300 \mathrm{~kg} / \mathrm{ha} \text { (T3) }\end{array}$ & $0,345 a$ & $39,68 b$ & $0,51 \mathrm{a}$ \\
\hline $\begin{array}{l}\text { Biochar } 5 \%+\text { Compost } 2.5 \% \\
+ \text { NPK } 600 \mathrm{~kg} / \mathrm{ha}(\mathrm{T} 2)\end{array}$ & $0,32 a b$ & $39,09 b$ & $0,39 b$ \\
\hline $\begin{array}{l}\text { Biochar } 5 \%+\text { Compost } 2.5 \% \\
\quad+\text { NPK } 300 \mathrm{~kg} / \mathrm{ha}(\mathrm{T} 1)\end{array}$ & $0,27 b$ & $33,73 b$ & $0,31 b$ \\
\hline Control (TO) & $0,20 c$ & $5,11 b$ & $0,10 c$ \\
\hline
\end{tabular}

Note: Figures within the same colums followed by the same letters were not significantly different at $5 \%$ significant level.

The effects of treatment packages on the soil base elements and soil base saturation levels by the end of experiment.

In general, all the treatment packages of biochar, compost, and low input of NPK had increased soil content of base elements mainly $\mathrm{K}, \mathrm{Ca}$, and $\mathrm{Mg}$. On the other hand, no treatment packages were able to increase soil $\mathrm{Na}$ content. Eventhough soil $\mathrm{Na}$ content at treatment 4 was highest than that of other biochar treatments, it is still no significantly different than that of control treatment.

Table 3. Soil Base Saturation Levels and Soil Base elements content of each treatment package by the end of the experiment.

\begin{tabular}{|c|c|c|c|c|c|}
\hline Treatment Pakacge & $\begin{array}{c}\text { K-dd } \\
\left(\mathrm{cmol}^{+}\right)\left(\mathrm{kg}^{-1}\right)\end{array}$ & $\begin{array}{c}\text { Ca-dd } \\
\left(\mathrm{cmol}^{+}\right)\left(\mathrm{kg}^{-1}\right)\end{array}$ & $\begin{array}{r}\text { Mg-dd } \\
\left(\mathrm{cmol}^{+}\right)\left(\mathrm{kg}^{-1}\right)\end{array}$ & $\begin{array}{r}\text { Na-dd } \\
\left(\mathrm{cmol}^{+}\right)\left(\mathrm{kg}^{-1}\right) \\
\end{array}$ & KB (\%) \\
\hline $\begin{array}{l}\text { Biochar } 10 \%+\text { Compost } \\
2.5 \% \text { +NPK } 600 \mathrm{~kg} / \mathrm{ha} \text { (T4) }\end{array}$ & $0,52 a$ & $3,40 a$ & $2,05 a$ & $0,57 a$ & $37,39 a$ \\
\hline $\begin{array}{l}\text { Biochar } 10 \%+\text { Compost } \\
2.5 \% \text { +NPK } 300 \mathrm{~kg} / \mathrm{ha} \text { (T3) }\end{array}$ & $0,51 \mathrm{a}$ & $2,76 b$ & $1,86 a b$ & $0,20 \mathrm{~b}$ & $35,23 a$ \\
\hline $\begin{array}{r}\text { Biochar } 5 \%+\text { Compost } \\
2.5 \%+\text { +NPK } 600 \mathrm{~kg} / \mathrm{ha}(\mathrm{T} 2)\end{array}$ & $0,38 b$ & $2,59 b$ & $1,63 b$ & $0,26 b$ & $32,64 a b$ \\
\hline $\begin{array}{r}\text { Biochar } 5 \%+\text { Compost } \\
2.5 \% \text { +NPK } 300 \mathrm{~kg} / \mathrm{ha}(\mathrm{T} 1)\end{array}$ & $0,31 b$ & $1,56 \mathrm{c}$ & $1,06 c$ & $0,28 b$ & $25,56 \mathrm{bc}$ \\
\hline Control (T0) & $0,10 c$ & $0,75 d$ & $0,36 \mathrm{~d}$ & $0,37 a b$ & $18,95 c$ \\
\hline
\end{tabular}

Note: Figures within the same colums followed by the same letters were not significantly different at $5 \%$ significant level.

The increase in soil base element contents has resulted in significantly increase of percentage of soil base saturation. Soil base element content and soil base 
saturation levels at the end of the experiment were presented in the following Table 3.

\section{The effects of treatment packages of biochar, compost and low input of NPK to other important soil characteristics.}

The results of this experiment also show that all the treatment packages of biochar, compost, and low input of NPK had significantly increased other important soil charactersistic such as soil $\mathrm{pH}, \mathrm{CEC}, \mathrm{C}$-organic content, and $\mathrm{C} / \mathrm{N}$ ratios, and it was also significantly decrease soil exchangeable content of $\mathrm{H}$ and Al. The increases in the status of soil C-organic, $\mathrm{K}, \mathrm{Ca}, \mathrm{Mg}$, and soil $\mathrm{CEC}$ were similar to the findings reported by Sukartono and Utomo (2012) and Carter et al, (2013). Furthermore, the effects of biochar treatments on the increases in soil $\mathrm{pH}$, C-total, available $\mathrm{P}$ and $\mathrm{K}$, and the decreases in soil exchangeable $\mathrm{H}$ and $\mathrm{Al}$ were similar to the findings reported by Zong et al. (2016).

Table 4. The characteristics of soil $\mathrm{pH}, \mathrm{CEC}, \mathrm{C} / \mathrm{N}$ ratio, and $\mathrm{C}-\mathrm{Org}$ content, exch-Al and exch-H for each treatment package by the end of the experiment.

\begin{tabular}{|c|c|c|c|c|c|c|}
\hline $\begin{array}{l}\text { Treatment } \\
\text { Package }\end{array}$ & pH & $\begin{array}{l}\text { C-Org } \\
(\%)\end{array}$ & $\begin{array}{c}\text { CEC } \\
\left(\mathrm{cmol}^{+}\right)\left(\mathrm{kg}^{-1}\right)\end{array}$ & $\begin{array}{l}\text { C/N } \\
\text { Ratio }\end{array}$ & $\begin{array}{c}\text { Exch-Al } \\
\left(\mathrm{cmol}^{+}\right)\left(\mathrm{kg}^{-1}\right)\end{array}$ & $\begin{array}{c}\text { Exch-H } \\
\left(\mathrm{cmol}^{+}\right)\left(\mathrm{kg}^{-1}\right)\end{array}$ \\
\hline $\begin{array}{c}\text { Biochar } 10 \%+ \\
\text { Compost } 2.5 \% \\
+ \text { NPK 600kg/ha } \\
\text { (T4) }\end{array}$ & $5,58 a$ & $3,21 a$ & $17,70 a$ & $8,65 a$ & $0,07 b$ & $0,18 a b$ \\
\hline $\begin{array}{c}\text { Biochar 10\%+ } \\
\text { Compost 2.5\% } \\
+ \text { NPK 300kg/ha } \\
\text { (T3) }\end{array}$ & $5,40 a b$ & $2,98 \mathrm{a}$ & $16,46 a$ & $8,69 a$ & $0,12 a b$ & $0,17 \mathrm{~b}$ \\
\hline $\begin{array}{c}\text { Biochar 5\% + } \\
\text { Compost 2.5\% } \\
+ \text { NPK 600kg/ha } \\
\text { (T2) }\end{array}$ & $5,25 b c$ & $2,79 a b$ & $15,14 a b$ & $8,71 a$ & $0,10 a b$ & $0,23 a b$ \\
\hline $\begin{array}{c}\text { Biochar 5\% + } \\
\text { Compost 2.5\% } \\
+ \text { NPK 300kg/ha } \\
\text { (T1) }\end{array}$ & $5,00 \mathrm{c}$ & $2,29 b$ & $12,64 b$ & $8,46 a$ & $0,13 a b$ & $0,24 a b$ \\
\hline Control (T0) & $4,57 d c$ & $1,64 \mathrm{c}$ & $9,01 \mathrm{c}$ & $8,06 \mathrm{~b}$ & $0,16 a$ & $0,30 a$ \\
\hline
\end{tabular}

Note: Figures within the same colums followed by the same letters were not significantly different at $5 \%$ significant level.

\section{CONCLUSION}

Results of the study indicated some findings as follows: All the treatment packages of rice husk biochar, compost and NPK compound had significantly increased not only the residue content of $\mathrm{N}, \mathrm{P}, \mathrm{K}$ nutrients within the soil, but also the content of element bases such as $\mathrm{K}, \mathrm{Ca}$, and $\mathrm{Mg}$, and soil base saturation level. Furthermore, all the treatment package of rice husk biochar, compost and NPK compound also had increased the other soil characteistics such as soil pH, CEC, Corganic content, $\mathrm{C} / \mathrm{N}$ ratio, and significantly decreased the content of soil exch-Al and soil exch-H by the end of the experiment. Soil amendment with rice husk biochar, compost, and NPK compound as low input treatment package in thie experiment had significantly increased corn growth and yield at upland soil of District of Toho, 
West Kalimantan. These results were paralel with the hyphotesis that the application of rice husk biochar, compost, and NPK compound in low inputs treatment package were able to increase corn growth and yield in suboptimal upland soil of West Kalimantan. The treatment package of $10 \%$ Biochar, $2,5 \%$ Compost, and $300 \mathrm{~kg} / \mathrm{ha}$ NPK compound (T3) set up as low input treatment had succesfully increased both the growth and yield of corn more than that of in recommended treatment (T4). Therefore, that treatment (T3) is highly recommended for one of technology packages that will be field tested in suboptimal upland soil in West Kalimantan.

\section{ACKNOWLEDGEMENTS}

This research was funded by Tanjungpura University through the DIPA scheme of fiscal year 2017. Thank to our Laboratory Staffs and students who had worked very hard for field and analytical works. We also greatly appreciated and deeply thank to the reviewers for their valuable comments.

\section{REFERENCES}

Brady, N.C. and Weil, R. R. (2008). An Introduction to the Nature and Properties of Soils. $14^{\text {th }}$ edition, Prentice Hall, Upper Saddle River, NJ.

Badan Pusat Statistik Kalimantan Barat. 2014. Kalimantan Barat Dalam Angka 2014. Badan Pusat Statistik Provinsi Kalimantan Barat.

Carter, S., Simon Shackley, Saran Sohi, Tan Boun Suy, ans Stephan Haefele. 2013. The Impact of Biochar Application on Soil Properties and Plant Growth of Pot Grown Lettuce (Lactuca sativa) and Cabbage (Brassica chinensis). Agronomy, 3:404-418. Doi:10.3390/agronomy3020404. www.mdpi.com/journal/agronomy

Cornelissen, G., Vegard Martinsen, Victor Shitumbanuma, Vanja Alling, G. D. Breedveld, David W. Rutherford, Magnus Sparrevik, Sarah E. Hale, Alfred Obia, and Jan Mulder. 2013. Biochar Effect on Maize Yield and Soil Characteristics in Five Conservation Farming Sites in Zambia. Agronomy, 3:256-274. ISSN 20734395. www.mdpi.com/journal/agronomy.

Downie, A., Crosky, A., and Munroe, P. (2009). 'Physical Properties of Biochar', Biochar for Environmental Management, pp 13-32.

Ekebafe, M.O, Lawrence Olu Ekebafe, and S. O. Ugbesia. 2015. Biochar compost $\begin{array}{lllll}\text { and composites. } & \text { Science Progress, } 98 \text { (2): }\end{array}$ www.scienceprogress.co.uk

Laine, J., Simoni, S. and Calles, R. (1991) 'Preparation of activated carbon from coconut shell in a small scale concurrent flow rotary kiln'. Chemical Engineering Communications. Vol 99, pp 15-23

Lehman and Joseph, S. (2009). Biochar for Environmental Management: An Introduction, Biochar for Environmental Management; Science and Technology, pg. 1

Miltner, B., and Oliver T. Coomes. 2015. Indigenous innovation incorporates biochar into swidden-fallow agroforestry systems in Amazonian Peru. Agroforest Syst. 89:409-420.

Ogundare, K., Samuel Agale, and Peter Aiyelari. 2012. Organic amendment of an ultisol: effects on soil properties, growth, and yield of maize in Southern Guinea 
savanna zone of Nigeria. International Journal of Recycling of Organic in Agriculture. 1:11. http://www.ijrowa.com/content/1/1/11.

Poux, X. 2007. Lowinput farming systems in Europe:What is at stake? Dalam LowlnputFarmingSystems:anOpportunity to DevelopSustainable Agriculture. Editors Katarzyna Biala, Jean-Michel TerresPhilippe Pointereau, Maria Luisa Paracchini. Proceedings of the JRC Summer University. Ranco, 2-5 July 2007

Sudjana, B. 2014. Pengaruh Biochar Dan NPK Majemuk Terhadap Biomas Dan Serapan Nitrogen Di Daun Tanaman Jagung (Zea mays) Pada Tanah Typic Dystrudept. Jurnal IImu Pertanian dan Perikanan. Vol.3.No.1. Hal:63-66. ISSN 2302-6308. http://umbidharma.org/jipp

Sukartono dan W.H. Utomo. 2012. Peranan Biochar Sebagai Pembenah Tanah Pada Pertanaman Jagung Di Tanah Lempung Berpasir (Sandy Loam) Semiarid Tropis Lombok Utara. Buana Sains, Vol 12 No 1: 91-98.

Suryana, I Made, I Putu Sujana, I Nyoman Labek Suyasdipura. 2016. Pengaruh Penambahan Dosis Beberapa Jenis Biochar Pada Lahan Yang Tercemar Limbah Cair Sablon Terhadap Pertumbuhan Tanaman Sawi Hijau. Prosiding Seminar Nasional Inovasi IPTEKS Perguruan Tinggi Untuk Meningkatkan Kesejahteraan Masyarakat. Fakultas Pertanian UNMAS Denpasar Bali, 29-30 Agustus 2016.

Tenanbaum, D. (2009) 'Biochar: Carbon Mitigation from the Ground Up', Environ News, innovations. Environ A70. Health Perspect. 2009. February;117(2):-A73.

Wildman, J. and Derbyshire, F. (1991). 'Origins and functions of macroporosity in activated carbons from coal and wood precursors'. Fuel, Vol 70, pp 655-661.

Wimmer, J. 2011. Biochar Research and a Case Study in Kansas. A Thesis, Submitted to the graduate degree program in Geography and the Graduate Faculty of the University of Kansas in partial fulfillment of the requirements for the degree of Master of Arts.

Yoo, G., H. Kim, J. Chen, Y. Kim. 2013. Effects of Biochar Addition on Nitrogen Leaching and Soil Structure following Fertilizer Application to Rice Paddy Soil. Soil Sci. Am. J. 78:852-860.

Zong, Y., Qing Xiao, Shenggao Lu. 2016. Acidity, water retention, and mechanical physical quality of a strongly acidic Ultisol amended with biochars derived from diffrent feedstokcs. J. Soils Sediments. 16:177-190. 